\title{
Stock Market Responses to Macroeconomic Dynamics: Testing for Long-Run Equilibrium in Nepal
}

\author{
Dipendra Karki \\ Lecturer, Nepal Commerce Campus
}

\begin{abstract}
This study empirically examines the macro-economic factors of the stock market performance in Nepal. It considers the annual data of four macroeconomic variables; real GDP, inflation, interest rate and broad money supply from 1994 to 2016 and attempts to reveal the relative influence of these variables on stock prices represented by 'NEPSE Index' of the Nepalese capital market. Empirical results reveal that the performance of stock market is found to respond positively to real GDP, inflation and money supply, and negatively to interest rate. More importantly, cointegrating evidence cannot be found between macroeconomic variables and stock market index which suggests that stock price movements in Nepal are not explained by the macroeconomic variables. It supports random walk hypothesis in Nepalese stock market.
\end{abstract}

Key words: Stock Market, Macroeconomy, Long-run Equilibrium

\section{INTRODUCTION}

\section{Background of the Study}

The overall development of the economy is a function of how well the stock market performs and empirical evidences have proved that development of capital market is indispensable for economic growth (Avadhani, 1996). It is through this segment that the country's exposure to the outer world is most readily felt. The relationship of economy and Stock price has always been a subject matter of controversial debate. The pricing implication has come into attention since the publication of seminal work of Markowitz (1952) - the mean-variance portfolio theory. Since then, the stock prices volatility has received a great attention from both academicians and practitioners as it can be used as a measure of risk in financial markets. Establishing the empirical link between volatility and macroeconomic variable has proven to be very challenging. Some studies find strong evidence that stock volatility increases during economic recessions (Bernanke, 1983). It seems that pricing volatility does not follow any pattern and not affected by economic variable. In some cases, it is closely related with macroeconomic variables and in some cases macroeconomic variables have no impact upon volatility. Varying evidences of relationship between macroeconomic variables with stock prices were widely documented in the existing literature.

Researchers were successful in finding a relationship between stock prices and the different macroeconomic indicators in countries like Lithuania (Pilinkus, 2009), 
Turkey (Kandir, 2008), and Jordan (Maghayreh, 2003). There is in fact a relationship between stock prices and certain macroeconomic indicators (Fama \& Schwert, 1977), those studies were mostly conducted in developed economies. While in the context of less developed economies, like Asian markets macroeconomic factors can't be reliable indicators for stock market price movements because of the inability of stock markets to fully capture information about the change in macroeconomic fundamentals (Fung and Lie, 1990). The relevance of the studies conducted on the developed economies is yet to be seen in the context of smaller, developing and under-developed capital markets.

The importance of stock markets as financial channels for saving and investment is gaining significant role in Nepalese economy. In general, volatility in the Nepal Stock Market is less than the average volatility of other developing countries (K.C, 2009). The reason is mainly low volume of trading equities due to low demand. However, in recent years pricing volatility has increased due to the increase in the volume of trading triggered by the speculative motives of investors. As evidenced from macroeconomic indicators of Nepal as of mid-July 2016, the ratio of stock market capitalization to GDP is about 94 percent. Macroeconomic stability, therefore, has become an important condition for financial development and economic growth of the country. In the light of these facts, it is necessary to examine how far stock market in Nepal is being influenced by macroeconomic variables.

The relationship between the stock price and macro-economic factors is important to study for many reasons. First, it helps policy makers understand the full effect of prevailing and upcoming policies and regulations. Second, if investors were aware of this relationship and fully understood it, then they will make more informed investment decisions thus reducing their exposure to risk. And third, knowing which factor leads the other can help in reducing the shock factor because the public will be somewhat aware of what might happen in the economy or the financial market and thus will be able to take protective measures. Economic liberalization and financial sector reforms in Nepal have guided in a change in the financial architecture of the economy. This leads to the number of banks and financial institutions come in to operation, widening the scope for a re-examination of the relationship between the stock market and the economic and non-economic variables in Nepal. This study is an endeavour in this direction.

\section{Statement of the Problem}

Stock market facilitates the situation of country's economy. Growth in stock market is normally considered as a good sign since it implies the investors are confident about the future prospect of the economy. Hence, it is essential that the policymakers keep eyes on the stock market development and macroeconomic indicators to take appropriate measures, if needs arise, to prevent the build-up of bubbles and collapse in the market. For this, it is necessary to understand the relationship between the stock market index and the macroeconomic factors that influence it.

Nepalese stock market has passed through different stages. Major political changes occurred during this recent decade and the market has jumped to all time high 1881.45 points on July 31, 2016 from all-time low of 292.31 points on June 15, 2011. What factors are responsible for these changes in volatility? Every individual 
specially related with stock market in this or that way, tries to get answer to these questions. Graham (1973) pointed out that stocks do well or poorly in the future because the businesses behind them do well or poorly-nothing more, and nothing less. Indeed in some markets, prices exhibit common movements that are hard to explain by movements in fundamentals (Watanabe, 2008). If fundamentals are not influential, then what else is responsible for changing stock prices over time? There are several studies which examined the movement in stock prices. Schwert (1989) correlated these changes to the volatility of macroeconomic variables. Similarly, many others attempted to relate changes in stock prices and economic variables, including Maghayreh (2003), Kandir (2008), and Alagidede and Panagiotidis (2010). Though there is no unanimous conclusion, the majorities of existing literature establish a link between macroeconomic volatility and stock market prices based on transmission mechanism between the key macroeconomic variables, namely, inflation, interest rate, money supply, GDP etc. Thus, to sum up, the study basically deals with following research issues:

- What is the direction and magnitude of causal relationship between stock market prices and macroeconomic variables in Nepal?

- Is there any long-run equilibrium relationship between stock market prices and macro-economy of Nepal?

\section{REVIEW OF LITERATURE}

The modern study on macroeconomic factors and stock prices can be traced back to 1930, when Fisher explained how the market rate of interest and inflation affected the stock prices (Fisher, 1930). Several extensions have been made on this model incorporating several macro-economic and other structural variables in determining the stock market prices. There are some models which describes about the stock valuation and its movements. Among them, Dow Theory, Random Walk theory and Efficient Market Hypothesis are important models.

\section{Dow Theory}

Dow Theory is considered as the pioneer work in technical analysis of stock pricing. Robert (1932) expounded and refined the original ideas into 3 basic tenets that served as the foundation of the Dow Theory. (a) The Primary Trend is Inviolate (b) The averages discount everything (c) The Dow Theory is not infallible

\section{Random Walk Theory}

Malkiel (1973) stated that the past movement or direction of the price of a stock or overall market cannot be used to predict its future movement. It is the occurrence of an event determined by a series of random movements - in other words, events that cannot be predicted. For example, one might consider a drunken person's path of walking to be a random walk because the person is impaired and his walk would not follow any predictable path. Applying the random walk theory to stocks suggests that stock prices change randomly, making it impossible to predict stock prices.

\section{Efficient Market Hypothesis (EMH)}

Fama (1970) used the phrase "Efficient Market" to describe the market price that 
fully reflects all available information. The efficient-market hypothesis (EMH) asserts that financial markets are "informationally efficient". That is, one cannot consistently achieve returns in excess of average market returns on a risk-adjusted basis, given the information publicly available at the time the investment is made. It is important to note, however, that in the empirical work to date, the usual procedure has been to infer market efficiency from the observed independence of successive price changes. There has been very little actual testing of the speed of adjustment of prices to specific kinds of new information.

\section{Review of Empirical Evidences}

It has been recognized in the recent years that stock markets cannot persistently function in isolation from the macroeconomic conditions. Thus macroeconomic variables that reflect the state of economy serve as the natural candidates for the common factors. Chen, Roll, and Ross (1986) identified four macroeconomic factors, namely changes in industrial production, changes in expected and unexpected inflation, changes in risk premium, and changes in term structure, as the fundamental macroeconomic forces in affecting stock market returns. They found a long-term equilibrium relationship between stock prices and relevant macroeconomic variables, between 1953 and 1984 in the US stock market.

Mukherjee and Naka (1995) found a long-run equilibrium relationship between the Japanese stock market and the six macroeconomic variables such as exchange rate, money supply, inflation, industrial production, long-term government bond rate and call money rate. Pethe and Karnik (2000) pointed that the changes in state of economy, as proxied by index of industrial production, could have a bearing on stock prices, but not the other round. There was no evidence to suggest that a revival of the stock market, in the sense of rising share prices, could be a leading indicator of the economy. Flannery and Protopapadakis (2002) reported the significant effect of consumer price index, PPI, and money supply on market value weighted returns. All three coefficients were significantly negative indicating that higher than anticipated inflation or money supply depressed equity values. Ibrahim and Aziz (2003) considered the interactions between the Malaysian equity market and four macroeconomic variables including real output, money supply, price level and exchange rate. The study found a positive long-run relationship between stock prices and industrial production. It also reported a positive relationship between stock prices and inflation in context of Malaysia.

Adel (2004) reported a reliably negative relation between stock prices and inflation; whereas the level of real economic activity affected the stock price positively. Gan, Lee, Yong and Zhang (2006) examined the co-integrating relationship and found the existence of long run equilibrium between NZSE index and the macroeconomic variables. The study observed that New Zealand stock returns could be consistently determined by the interest rate, money supply and real GDP. Kandir (2008) investigated the role of macroeconomic factors in explaining Turkish stock prices. The study revealed significant effects of exchange rate and interest rate on stock returns. Similarly, inflation rates were found positively related to the stock prices. The study demonstrated a negative relation between stock returns and interest rate meaning that investors tended to invest less in stocks when interest rate rise causing stock prices to fall. Pilinkus (2009) analyzed relationship using Granger causality tests and 


\section{Pravaha Journal-2018}

revealed that some macroeconomic variables, for example, GDP deflator, net export, foreign direct investment, could lead stock market returns, while some variables such as GDP, material investment, construction volume index were led by the stock market index.

The study by Abu-Libdeh and Harasheh (2011) indicated a significant relationship between the macroeconomic variables and stock prices. Moreover, the causality analysis negated any kind of causal relationships between macroeconomic variables and stock prices. Osamwonyi and Osagie (2012) used Vector Error Correction Model (VECM) to study the short-run dynamics as well as long-run relationship between the stock market index and the selected macroeconomic variables and found that the macroeconomic variables influence stock market index in Nigeria. These studies have formed a base for the long-run relationship and short-run dynamic interactions among macroeconomic variables and stock market prices. Gross domestic product is one of the fundamental macroeconomic variables employed in the past studies to trace out macroeconomic influences on stock market prices. GDP is used as a proxy of real aggregate economic activity in an economy. The empirical studies associated with macroeconomic influences on stock returns have suggested mix evidences about GDP influence. Aggregate money supply in the economy and the rate of inflation are another interrelated macroeconomic variables influencing stock market performances. The empirical evidences on relationship between inflation and stock returns found that holding of stocks provides a good hedge (Ibrahim \& Aziz, 2003, and many others). This study also assumes the positive relationship of inflation and money supply on stock prices. Besides GDP, money supply and inflation, the interest rate risk is found to be another important financial and economic factor affecting the value of common stocks. To sum up, many studies have documented that macroeconomic variables do influence stock market prices and hence the stock returns, though the results are not consistent.

\section{Review of Nepalese Studies}

Though there are number of studies associated with macroeconomic volatility of stock returns and analysis on the impact of major events in context of US and other developed capital markets, there are few empirical works in the context of Nepal. G.C. and Neupane (2006) conducted the study entitled as "Stock Market and Economic Development: a Causality Test". The study found the empirical evidence of long-run integration and causality of macroeconomic variables and stock market indicators in Nepal. In econometric sense, it depicts that the stock market plays significant role in determining economic growth and vice versa. However, Baskota (2007) concluded that there is no persistence of volatility in Nepalese Stock Market and stock price movements are not explained by macro-economic variables.

The dynamic relationship among the market indexes and macroeconomic factors was studied by Bhattarai and Joshi (2009) and documented both short-run and longrun interdependence among stock index and some macroeconomic variables. Shrestha and Subedi (2014) revealed that the performance of stock market is found to respond positively to inflation and broad money growth, and negatively to interest rate. This suggests that, in Nepal, share investors seem to take equity as a hedge against inflation and consider stock as an alternative financial instrument. Further, availability of liquidity and the low interest rates stimulate the performance of the Nepalese stock 
market.

Many of the studies on the impact of some leading macroeconomic variables on stock prices concluded that one or other macroeconomic variables can predict stock market returns although the results vary among the studies. The findings associated with the studies on macroeconomic influences on stock prices in the context of Nepal also vary across the studies as in the case of developed capital markets. Though much of literatures are available in developed and developing economies, there are only few studies of this type in the context of Nepal. Thus, this study serves as an attempt to identify the cointegrating evidence between macro-economy and stock market performance in Nepal with a different set of variables, events and data of more recent period.

\section{RESEARCH METHODOLOGY}

\section{Conceptual Framework}

Many researchers have related several macroeconomic variables in existing literature affecting stock prices. The majorities of them basically focused on the several proxies of macro-economy like; real GDP, Inflation (INF), Interest Rate (IR), and Broad Money Supply (M2), whereas stock price is represented by the market index (measured as NEPSE Index in Nepal). Based on the literature review the conceptual framework of the study is presented as follows:

\section{Figure 1}

Conceptual Framework for Macroeconomic Factors Influencing Stock Prices.

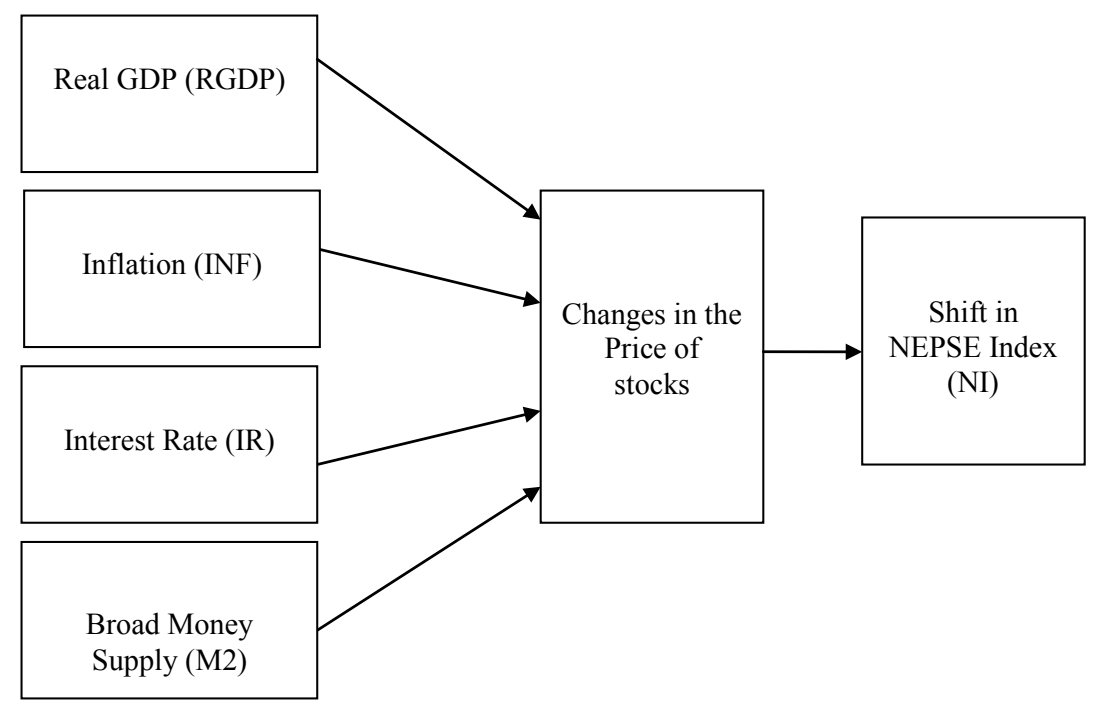

\section{Research Design}

This study adopts descriptive and causal comparative research designs to deal with the macroeconomic factors influencing stock prices in the context of Nepal. The descriptive research design has been adopted for fact-finding and searching adequate 
information about factors affecting stock market prices. The causal comparative research design has been used to ascertain and understand the directions, magnitudes and forms of observed relationship among the used variables such as real GDP, inflation, interest rate, and money supply. This study follows positivism research paradigm. From an ontological stand point, this paradigm assumes that there is universal single truth and reality is out there (Jennings, 2001).

\section{Nature and Sources of Data}

This study is an empirical research based on secondary data. Based on the literature review, the stock market price is influenced by several macroeconomic factors and among them inflation, interest rate, broad money supply and real GDP are found to be more important. The necessary annual data related to macroeconomic variables are collected from Central Bureau of Statistics (CBS), and Nepal Rastra Bank (NRB), whereas stock market indices data are collected from Nepal Stock Exchange Ltd. (NEPSE). The study uses the time series data for the total period of 23 years from fiscal year 1994 to 2016. The following data are taken to examine the response of stock market to macroeconomic dynamics in Nepal as shown in Table 1.

Table 1

Variables and their Description

\begin{tabular}{|lll|}
\hline Variable & Description & Unit \\
\hline NI & NEPSE Index & \\
GDP & Annual real GDP at basic price (Base year = 2000/01) & Rs in million \\
Inflation & Annual growth & Percent \\
Interest Rate & Weighted average 91 days T -bills rate, Annualized & Percent \\
M2 & Broad Money Supply & Rs in million \\
\hline
\end{tabular}

\section{Population and Sampling}

The study uses the time series data of macroeconomic indicators and stock market prices for analysis purpose. Nepal Stock Exchange Ltd (NEPSE) established in 1993 is the only capital market of the country who index has been used as dependent variable. This study attempts to cover the data since the inception of NEPSE to the recent period. During this period, Nepalese stock market passed through different stages. Major social, economic and political changes occurred during this period and the market has plunged to the all-time low of 292.31 points on June 15,2011 from all time high 1881.45 points on July 31,2016 . Due to this scenario, the aforesaid sample period seems to be comprehensive and appropriate.

\section{Methods of Data Analysis}

The methodology used to examine the long-run equilibrium is the cointegration test followed by Error Correction Model (ECM). The modeling strategy in this study is based on the widely used Engle-Granger methodology (Engle \& Granger, 1987).

First, the regression (OLS) equation has been estimated;

$$
\mathrm{NI}=a+\beta_{1} \mathrm{RGDP}+\beta_{2} \mathrm{INF}+B_{3} \mathrm{IR}+\beta_{4} \mathrm{M}_{2}+\varepsilon
$$


Where,

$\mathrm{NI}=$ NEPSE Index, RGDP = Real gross domestic product, INF = Inflation

$\mathrm{IR}=$ Interest rate, M2 = Broad money supply, $\mathrm{t}=1994-2016$

$\mathrm{a}=$ Constant term, assume to be constant over time.

$\varepsilon=$ Stochastic error term with the conventional statistical properties and $B_{1}, B_{2}, B_{3}$ and $B_{4}$ are the respective parameters of the explanatory variables to be estimated.

\section{Long-Run Equilibrium Analysis:}

Following are the steps involved to analyze the long-run equilibrium relationship between stock prices and macroeconomic variables:

(i) Unit Root Test

Running a regression of non-stationary variables may lead to spurious regression problem. To this end, the augmented Dickey-Fuller (ADF) test of stationarity has been performed both on the levels and the first differences of the variables (Dickey \& Fuller, 1981). A series is integrated of order d, I(d) if it can be difference $d$ times to achieve stationarity.

$\Delta \mathrm{y}_{\mathrm{t}}=\beta+\delta_{\mathrm{t}}+\alpha \mathrm{y}_{\mathrm{t}-1}+\sum_{\mathrm{i}=1}^{\mathrm{k}} \varphi_{\mathrm{i}} \Delta \mathrm{y}_{\mathrm{t}-\mathrm{i}}+\varepsilon_{\mathrm{t}}$

Where, $\mathrm{y}_{\mathrm{t}}=$ the level of the variable under consideration, $\mathrm{t}=$ time term,

$\varepsilon_{\mathrm{t}}=$ normally distributed error term with zero mean and constant variance.

(ii) Cointegration Test

Cointegration test is performed to identify the existence of a long-run relationship. According to Engle and Granger (1987), the stationarity of the residuals of the regression implies that the series are cointegrated.

$\mathrm{Yt}=6 \mathrm{Xt}+\varepsilon \mathrm{t}$

Where, both $\mathrm{Y}_{\mathrm{t}}$ and $\mathrm{X}_{\mathrm{t}}$ are non stationary variables and integrated of order 1 (i.e. $\mathrm{Y}_{\mathrm{t}} \sim \mathrm{I}(1)$ and $\left.\mathrm{X}_{\mathrm{t}} \sim \mathrm{I}(1)\right)$. In order for $\mathrm{Y}_{\mathrm{t}}$ and $\mathrm{X}_{\mathrm{t}}$ to be cointegrated, the necessary condition is that the estimated residuals from Eq. (3) should be stationary (i.e. $\left.\varepsilon_{\mathrm{t}} \sim \mathrm{I}(0)\right)$. The cointegration implies the existence of a long-run or equilibrium relationship among variables.

(iii) Error Correction Model (ECM)

The ECM helps to capture the rate of adjustment taking place among the various variables to restore long-run equilibrium in response to short-term disturbances. According to the Granger representation theorem (Granger, 1983; Engle \& Granger, 1987), if a set of variables are cointegrated, then there exists a valid error-correction mechanism. Hence, a necessary and sufficient condition for cointegration is the existence of an error correction mechanism (ECM). If dependent variable NI is denoted as $\mathrm{y}_{\mathrm{t}}$ and the entire explanatory variables in equation (2) as $x_{t}$, there exist an error-correction representation of the form: 
$\mathrm{Zt}=\mathrm{yt}-\mathrm{Bxt}$

Given that;

$\Delta \mathrm{y}_{\mathrm{t}}=\alpha_{1}+\phi_{1}\left(\beta^{\prime} \mathrm{z}_{\mathrm{t}-1}\right)+\sum_{\mathrm{i}=1}^{\mathrm{k}} \varphi_{\mathrm{j}}^{\prime} \Delta \mathrm{z}_{\mathrm{t}-\mathrm{j}}+v_{\mathrm{t}}$

$\Delta \mathrm{x}_{\mathrm{t}}=\alpha_{2}+\phi_{2}\left(\beta^{\prime} \mathrm{z}_{\mathrm{t}-1}\right)+\sum_{\mathrm{i}=1}^{\mathrm{k}} \lambda_{\mathrm{j}}^{\prime} \Delta \mathrm{z}_{\mathrm{t}-\mathrm{j}}+\mathrm{v}_{\mathrm{t}}$

Where, $\mathrm{Z}_{\mathrm{t}}$ refers to deviation of a variable from its long-run path given by $I(1)$ variables and $v_{t}$ and $v_{t}$ are well-behaved error terms and $|\varphi 1|+|\varphi 2| \neq 0$.

Conditional on finding cointegration between $\mathrm{Y}_{t}$ and $\mathrm{X}_{\mathrm{t}}$, the estimated residuals (B) from the first step long-run regression (3) may then be imposed in the error correction term $\left(\mathrm{Y}_{\mathrm{t}}-\mathrm{BX} \mathrm{X}_{\mathrm{t}}\right)$ in the following equation.

$\Delta \mathrm{Yt}=\mathrm{a} 1 \Delta \mathrm{Xt}+2(\mathrm{Y}-\mathrm{BX}) \mathrm{t}-1+\varepsilon \mathrm{t}$

Where, $\Delta$ represents first-differences and $\mathrm{t}$ is the error term. Note that the estimated coefficient $\alpha 2$ in the equation should have a negative sign and be statistically significant. Note also that, to avoid an explosive process, the coefficient should take a value between -1 and 0 . According to the Granger Representation Theorem (GRT), negative and statistically significant $\alpha 2$ is a necessary condition for the variables in hand to be cointegrated.

\section{DATA PRESENTATION AND ANALYSIS}

\section{Descriptive statistics}

Descriptive statistics for the NEPSE index and macroeconomic variables over the sample period (1994-2016 A.D.) are reported in Table 2. It shows that the NEPSE index ranges from minimum 163.40 to maximum 1718.2 with a mean value of 480.93 over the sample period. The volatility in NEPSE index indicated by coefficient of variation has been noted at 0.796 during the period, which shows that the price index posses high volatility. The inflation during the period ranges from minimum 2.48 to maximum 11.61 with an average of 7.49 for the period. The coefficient of variation of the inflation is only 0.383 . Similarly, interest rate varies within the range of 0.13 to 10.93 percent with the coefficient of variation of 0.686 during the period. The volatility with respect to real GDP and M2 are 0.252 and 0.332 respectively. The volatility with respect to real GDP is the minimum 0.252 than all other variables.

Table 2

Descriptive Statistics of Macroeconomic Variables and Stock Index

The table 2 shows the descriptive statistics. The variables are stock prices measured as NEPSE index (NI), real gross domestic product (RGDP), inflation (INF), interest rate (IR) defined as the annualized weighted average 91 days T-bills rate, and broad money supply (M2).

\begin{tabular}{lccccc}
\hline \multicolumn{1}{c}{ Statistics } & NEPSE Index & RGDP (billion) & Inflation (INF) & Int. Rate (IR) & M2 \\
\hline Mean & 480.93 & 4.85 & 7.49 & 4.25 & 16.65 \\
Median & 360.70 & 4.63 & 7.62 & 3.52 & 16.10 \\
Std. Deviation & 382.71 & 1.22 & 2.87 & 2.92 & 5.53 \\
\hline
\end{tabular}


Pravaha Journal-2018

\begin{tabular}{lccccc}
\hline \hline \multicolumn{1}{c}{ Statistics } & NEPSE Index & RGDP (billion) & Inflation (INF) & Int. Rate (IR) & M2 \\
\hline Coeff. of & 0.796 & 0.252 & 0.383 & 0.686 & 0.332 \\
variation & 1.743 & 0.329 & -0.480 & 0.691 & -0.149 \\
Skewness & 2.784 & -1.089 & -0.921 & -0.158 & -0.345 \\
Kurtosis & 163.40 & 3.09 & 2.48 & 0.13 & 4.4 \\
Minimum & 1718.2 & 6.95 & 11.61 & 10.93 & 27.3 \\
Maximum & 19.07 & 1.239 & 1.698 & 1.853 & 0.199 \\
JB test & 0.007 & 0.538 & 0.427 & 0.396 & 0.905 \\
p- value & & & & &
\end{tabular}

Jarque-Bera (JB) test of normality shows that distribution of macroeconomic time series data are normal in all cases. Real GDP (RGDP) has taken log values to smoothen the data. The p-values for JB statistics are greater than 10 percent in all cases except NI, which do not reject the normality hypothesis meaning that time series are normally distributed.

Figure 2

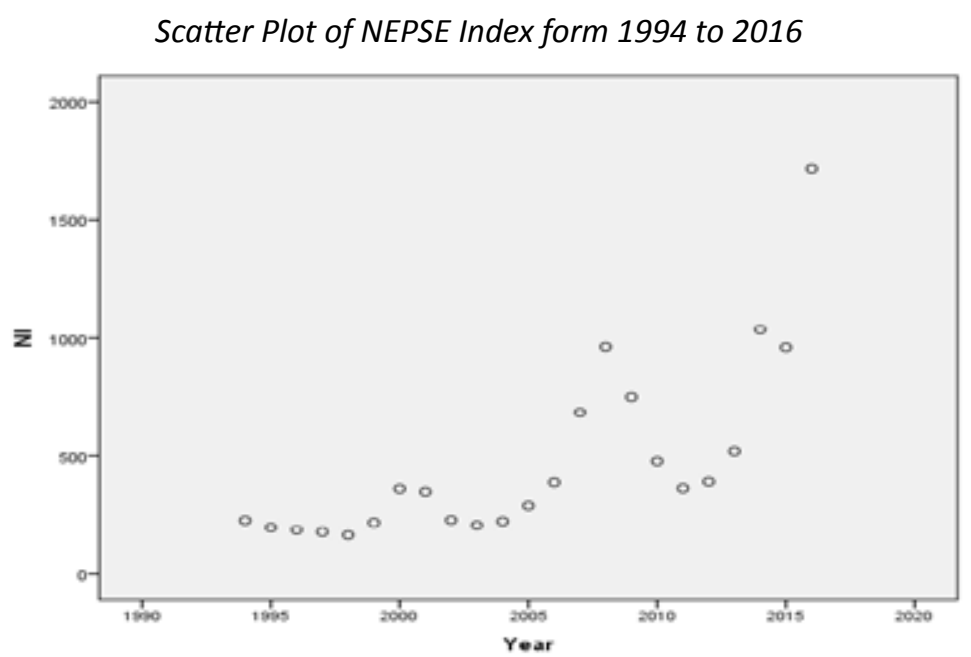

The figure 2 illustrates the volatility of stock market from 19994 to 2016 . It clearly states that the returns which is proxied by NEPSE Index does not remain constant over the period. It changes over time. It is observed that in 1995, NEPSE returns is low whereas in 2016 it seems to be high at a time.

\section{Correlation Analysis}

The correlation between the macroeconomic variables and stock market index has been presented in Table 3 which summarizes the correlation matrix with Pearson correlation coefficients in the lower left triangle and Spearman rank correlation coefficients in the upper right triangle that explain the direction and magnitude of relationship among different pairs of macroeconomic variables during the period 1994 to 2016 with market index (NI). It indicates that the stock market prices represented by NEPSE Index has positive relationships with real GDP, inflation, and broad money 
supply (M2) but has negative correlation with interest rate as expected. The negative relationship with interest rate, as hypothesized, indicates that the stock returns goes on decreasing when market interest rate increases. Investors will be reluctant to have borrowing at higher rate of interest and use it to stock investing. It validates the results by Kandir (2008) among many others.

Table 3

Pearson and Spearman Correlation Matrix

\begin{tabular}{lccccc}
\hline \multicolumn{1}{c}{ Variables } & NI & l_RGDP & INF & IR & M2 \\
\hline NI & 1 & $0.867^{* * *}$ & 0.331 & $-0.540^{* * *}$ & 0.348 \\
l_RGDP & $0.738^{* * *}$ & 1 & 0.353 & $-0.632^{* * *}$ & 0.156 \\
INF & 0.401 & 0.360 & 1 & 0.013 & $0.517^{* *}$ \\
IR & $-0.501^{* *}$ & $-0.629^{* * *}$ & -0.067 & 1 & -0.260 \\
M2 & 0.406 & 0.208 & $0.543^{* * *}$ & -0.214 & 1 \\
\hline
\end{tabular}

Note: Bi-variate Pearson correlation coefficients are in the lower left triangle and Spearman rank correlation coefficients are in upper right triangle. I_RGDP is the log value of real GDP. '**' sign indicates that correlation is significant at 5 percent level and ${ }^{\text {***' }}$ indicates that correlation is significant at 1 percent level.

Both the Pearson and Spearman correlation coefficients indicate the significant relationship between stock market index (NI) and real GDP and interest rate (IR). The statistical significance for the relationship between IR and NI (-0.540) is higher in Spearman rank correlation matrix where it is significant at $1 \%$ level compare to $5 \%$ level of significance in Pearson correlation matrix. The statistically significance of the result indicates that relationship between interest rate and NEPSE index is negative as it is hypothesized. This result approximately indicates that interest rate level in Nepal plays an important role to predict the stock market returns. The priori expected sign for the relationship of all variables with stock prices are maintained as prior studies by Ibrahim and Aziz (2003), and many others. However, the money supply and inflation has limited ability to explain the variation in stock prices as they do not posses statistical significance. This result contradicts the findings by Flannery and Protopapadakis (2002).

Similarly, the observed significant positive relationship between NEPSE and real GDP is consistent with priori expectation. This result is consistent with Adel (2004), and Pilinkus (2009), among others, who reported reliably positive relationship between stock market returns and real activity proxied by GDP, and inconsistent with earlier studies by Flannery and Protopapadakis (2002) who observed significant negative relationship between real GDP and stock market returns. This result again gives an approximate indication that development in real sector activity may contribute positively to the stock market.

The statistically significant positive correlation has been obtained in between money supply (M2) and inflation in both Pearson (0.543) and Spearman rank correlation matrix (0.517). This indicates that increasing the level of money supply increases the inflation subsequently. Similarly, The observed statistically significant negative relationship between interest rate and GDP on both Pearson (-0.501) and Spearman rank correlation coefficients (-0.632) may give a meaningful conclusion that decrease in interest rate attracts most investors toward real sector investment rather than 
bank deposit. However, statistical inferences about the causal relationship between different pairs of these macroeconomic variables cannot be drawn simply based on the correlation analysis.

\section{Regression Analysis}

The OLS regressions results have been reported in Table 4. The model specifications I through IV report the simple regression, where stock prices represented by NEPSE index (NI) have been regressed on different macroeconomic variables individually. The full version of the model has been reported in specification $\mathrm{V}$, where all the macroeconomic variables have been used as explanatory variables.

\section{Table 4}

Estimated Relationship from Regression of Stock Prices (NI) on Macroeconomic Variables

Model: $N I t=\alpha+61 t R G D P t+62 t I N F t+63 t I R t+64 t M 2 t+\varepsilon t$

Dependent Variable : NEPSE Index (NI)

\begin{tabular}{|c|c|c|c|c|c|}
\hline Model & I & II & III & IV & V \\
\hline Intercept & $-14122.2^{* * * *}$ & 80.56 & $760.50^{* * * *}$ & 13.83 & $-12741.8^{* * *}$ \\
\hline mtercep & $(-3.44)$ & $(0.73)$ & (3.97) & $(0.14)$ & $(-3.18)$ \\
\hline 1_RGDP & $\begin{array}{c}1118.11 \\
(3.52)\end{array}$ & & & & $990.02^{* * *}$ \\
\hline JNF & & $53.45^{* *}$ & & & 3.99 \\
\hline $1 \mathrm{NI}$ & & $(2.22)$ & & & $(0.29)$ \\
\hline IR & & & $-65.84^{* *}$ & & -4.72 \\
\hline & & & $(-2.32)$ & $2805 * *$ & $(-0.24)$ \\
\hline M2 & & & & $\begin{array}{c}2.00 \\
(2.75)\end{array}$ & $(4.46)$ \\
\hline $\mathrm{F}$ & $12.38 * * *$ & $4.94^{* *}$ & $5.38^{* *}$ & $7.54^{* *}$ & $11.94 * * *$ \\
\hline Adj. R2 & 0.523 & 0.121 & 0.216 & 0.125 & 0.526 \\
\hline SEE & 264.27 & 358.84 & 338.90 & 358.04 & 263.53 \\
\hline DW & & & & & 0.927 \\
\hline
\end{tabular}

Note: The reported values are intercepts and slope coefficients of respective explanatory variables with $t$-statistics in the parentheses. The results also include the values of F-statistics (F), adjusted coefficient of determination (Adj. R2), and standard error of estimates (SEE). The triple asterisk (***) sign indicates that result is significant at 1 percent level, and double asterisk (**) sign indicates that result is significant at 5 percent level.

The priori expected sign of all the variables RGDP (1118.11), INF (53.45), IR (-65.84), and M2 (28.05) holds true for each individual regression model and are statistically significant in their coefficients as well as in terms of model specification. This shows that the selected macroeconomic variables have significant impact on stock prices. In multiple regression model $\mathrm{V}$, only two variables real GDP and broad money supply (M2) have maintained their statistical significance at 1\% level. We could explain that $1 \%$ change in broad money supply changes the stock index by 16.98 points. The statistical significance implies that real GDP and the broad money supply (M2) among others are the important macroeconomic variables to determine the movement of stock prices. 
The full model $\mathrm{V}$ also shows the statistical significance in terms of F-statistics (11.94) at $1 \%$ level of significance. The inability of the variables; inflation and interest rate to show statistical significance in the full model may be interpreted as the reason of other variables that subsume the effect of them. Though there is no encouraging growth of GDP in Nepal, the earlier studies have documented the positive contribution of GDP in moving stock prices. Similarly, this study also found statistically significant positive relationship of GDP with stock prices in full model, which is consistent with the findings of Chen, Roll and Ross (1986) and many others. However, the result contradicts the findings of Flannery and Protopapadakist (2002) and Baskota (2007).

The simple regression result shows the positive and a significant relationship between inflation and stock prices in line with priori expectation. This results support the findings of Mukherjee and Naka (1995) but contradicts the result of Adel (2004). With respect to interest rate effect, it is believed that a reduction in interest rates (IR) induces an injection of liquidity into the economy as such that this extra liquidity could be channeled to the stock market thus driving up the demand and prices of stocks; with the assumption that an increase in interest rate tends to decrease the prices of stock. The observed sign in the present study is negative and statistically significant in simple regression model III as presented in the table 4 . which is in line with priori expectation. This results support the findings of several studies including; Gan, Lee, Yong and Zhang (2006), and Kandir (2008).

Future economic activity is correlated with increased domestic borrowing or increased supply of money. This simply means that an increase in domestic borrowing or issuance of money has inflationary effects that dampen real activity. In the end, stock market prices also rise due to rise in the inflation. As expected, it has noted the positive and a significant relationship between broad money supply (M2) and stock prices. The statistically significant positive relationship between stock prices and money supply is consistent with the findings of Adel (2004) but contradicts the findings of Flannery and Protopapadakis (2002), who found negative relation of money supply on stock prices.

\section{Test for Long-Run Equilibrium}

One of the major objectives of this study is to examine the long-run equilibrium between stock prices and macroeconomic variables. The empirical studies associated with macroeconomic influences on common stock prices have documented a causal relationship between stock prices and macroeconomic variables. For example, Ibrahim and Aziz (2003) examined the effect of macroeconomic variables and found that stock prices have positive long-run relationship with real GDP. Therefore, it is a matter of interest to explore whether macroeconomic variables such as real GDP, inflation, interest rate, and money supply could capture the variation in stock market prices. The methodology employed to test long-run equilibrium in this study is the cointegration test and the modeling strategy adopted is based on the widely used Engle-Granger methodology (Engle \& Granger, 1987). The steps involved for cointegration test are described as follows:

\section{a. Stationarity/Unit Root test}

First step is to determine whether the variables used are stationary or non-stationary. Many macroeconomic time series contain unit roots dominated by stochastic trends as developed by Nelson and Plosser (1982). Knowing that 
unit root tests are sensitive to the presence of deterministic regressors, tests for each variable then is performed on both levels and first differences. Table 5 reports the results of Augumented Dickey Fuller (ADF) test for the model without constant and no trend, and with constant and no trend.

According to Table 5, investigating the stationary of variables using ADF test shows that none of the variables were stationary at the level and become stationary after first order difference. Hence it is concluded that the variables are integrated of order one I(1). This result is consistent to the finding of Nelson and Plosser (1982) that most of macroeconomic variables are non-stationary at level, but they are stationary after first differencing.

Table 5

Augmented Dickey-Fuller Test for Unit Roots of the Variables

\begin{tabular}{lcccc}
\hline \multirow{2}{*}{ Variables } & \multicolumn{2}{c}{ With Constant and no Trend } & \multicolumn{2}{c}{ With Constant and Trend } \\
\cline { 2 - 5 } & Level & First Difference & $\begin{array}{c}\text { Level } \\
(\tau)\end{array}$ & \multirow{2}{*}{ First Difference } \\
\hline \multirow{2}{*}{ NI } & $(\tau)$ & $-3.709^{* * * *}$ & -0.803 & $-3.735^{* *}$ \\
& 0.699 & $(0.004)$ & $(0.950)$ & $(0.020)$ \\
l_RGDP & $(0.989)$ & $-3.695^{* * *}$ & -2.114 & $-3.549^{*}$ \\
& -0.834 & $(0.004)$ & $(0.510)$ & $(0.059)$ \\
INF & $(0.789)$ & $-6.822^{* * *}$ & -3.084 & $-6.690^{* * *}$ \\
& -2.656 & $(0.000)$ & $(0.134)$ & $(0.000)$ \\
IR & $(0.098)$ & $-4.199^{* * *}$ & -2.539 & $-4.078^{* *}$ \\
& -1.831 & $(0.004)$ & $(0.308)$ & $(0.021)$ \\
M2 & $(0.356)$ & $-5.302^{* * *}$ & -3.193 & $-5.168^{* * *}$ \\
& -3.103 & $(0.000)$ & $(0.111)$ & $(0.002)$ \\
\hline
\end{tabular}

Critical Values

\begin{tabular}{lll}
$1 \%$ & -2.66 & -3.75 \\
$5 \%$ & -1.95 & -3.00 \\
$10 \%$ & -1.60 & -2.62 \\
\hline
\end{tabular}

Note: The Table 5 shows the unit root tests of the macroeconomic variables for the period of 1994 to 2016 using Augmented Dickey Fuller criteria. The variables are NEPSE Index (NI), real gross domestic product (RGDP), rate of inflation (INF), interest rate (IR) defined as the annualized weighted average of 91 days treasury bills rate and the growth rate of broad money supply (M2). As the plot of the data suggests, model without constant and no trend is avoided. Probabilities are in parentheses. ${ }^{* *},{ }^{* *}$, and ${ }^{*}$ denote rejection of the unit root hypothesis at $1 \%, 5 \%$, and $10 \%$ respectively. Tests for unit roots have been carried out on Gretl software.

\section{b. Cointegration test}

Testing for Cointegration (long-run equilibrium) entails testing the order of integration of the error term in the relationship. For the purpose of this study therefore, testing for Cointegration implies testing for stationarity in the residuals of the regression equation. In order to estimate the long-run relationship between variables using the Engle-Granger integration technique, first, it is to find the optimal order of the VAR model using lag determining criteria. 
Table 6

Number of Optimal Lag Using Schwarz-Bayesian Criteria

\begin{tabular}{cc}
\hline Number of Lags & Schwarz-Bayesian Criteria \\
\hline 3 & 181017 \\
2 & 14.536 \\
1 & $14.395^{*}$ \\
\hline
\end{tabular}

* indicates amount of optimal lag

According to the above Table 6, it can be claimed that optimal lag of the VAR model regarding the Schwarz -Bayesian criteria is one.

The test for Cointegration has been conducted using the residuals based method of Engle and Granger (1987). According to them, if the residuals obtained from the above static regression are stationary, it implies that the variables are cointegrated. Hence, there is a tendency for the variables to move together in the long-run even though the variable may wander or drift individually apart. The results obtained using the Engle and Granger (1987) Cointegration test is presented in Table 7.

Table 7

Cointegrating Regression: OLS Estimates of the Long-run Model

\begin{tabular}{|c|c|c|c|c|}
\hline Dependent variable & Independent variables & \multirow{2}{*}{$\begin{array}{l}\text { Coefficient } \\
72390.5\end{array}$} & \multirow{2}{*}{$\frac{\mathrm{t}-\text { Statistics }}{1.407}$} & \multirow{2}{*}{$\begin{array}{l}\text { Probability } \\
0.177\end{array}$} \\
\hline \multirow[t]{11}{*}{ NI } & Const & & & \\
\hline & 1_GDP & -5771.45 & -1.413 & 0.175 \\
\hline & INF & -20.93 & -0.725 & 0.478 \\
\hline & IR & 5.759 & 0.222 & 0.827 \\
\hline & M2 & 31.339 & 2.122 & $0.048 * *$ \\
\hline & Time & 256.597 & 1.660 & 0.115 \\
\hline & $\mathrm{R} 2$ & 0.666 & & \\
\hline & Adj. R2 & 0.568 & & \\
\hline & S.D. dep. var & 382.71 & & \\
\hline & Durbin-Watson & 1.131 & & \\
\hline & S.E. of Regression & 251.546 & & \\
\hline \multicolumn{5}{|c|}{ Stationarity Test of Residual } \\
\hline $\begin{array}{cc}\text { Test } & \mathrm{Nu} \\
\text { variable } & \text { Hypot } \\
\end{array}$ & $\begin{array}{c}\text { Test statistics } \\
(\tau)\end{array}$ & p-value & Null hypothesis & Result \\
\hline $\begin{array}{r}\text { Residua } \\
\text { statio }\end{array}$ & $\begin{array}{l}\mathrm{lis} \text { not } \\
\text { nary }\end{array}$ & 0.957 & $\begin{array}{l}\text { Could not be } \\
\text { rejected }\end{array}$ & $\begin{array}{c}\text { Residual is not } \\
\text { stationary }\end{array}$ \\
\hline
\end{tabular}

The result in Table 7 indicates that unit root hypothesis of no stationarity (null hypothesis of no cointegration) could not be rejected for the residuals ( $\hat{u})$ since $p$-value is 0.957 . This shows that there is no evidence for the existence of cointegrating relationship among the variables used and therefore do not maintain long-run equilibrium. This concludes that there is no cointegration and long-run equilibrium between included macroeconomic variables and stock 
prices in the context of Nepal. This result contradicts the findings by Chen, Roll and Ross (1986), Ibrahim and Aziz (2003), Abu-Libdeh and Harasheh (2011), Osamyoni and Osagie (2012), among others. It also contradicts the findings by G.C., and Neupane (2006) and Bhattarai and Joshi (2009) in Nepalese context. However, this result is consistent with the findings by Pethe and Karnik (2000) and also supports the findings by Baskota (2007) in Nepalese context.

\section{c. $\quad$ Error Correction Model (ECM)}

The necessary and sufficient condition of cointegration is existence of ECM which indicates the speed of adjustment if the variables are cointegrated. When there is no cointegration, there does not exist ECM. We do not need to test for ECM further. If require otherwise to test for ECM, the residual from OLS regression shall be included in the ordinary least square regression of the variables whose first differences are considered. The lag value of order 1 is taken for the independent variables used to run the model. The ECM describes the short-run dynamics consistent with the long-run relationship. The estimated coefficient of error correction term measures the speed of adjustment to restore equilibrium in the dynamic model. The results though not significant, shows the expected negative sign for the residual (i.e Residual $\left(\hat{u}_{t-1}\right)=-0.341$ ) which is the necessary condition for error correction model.

\section{Model Specification and Diagnostic Checking}

To ensure the robustness of the estimation process, model specification and diagnostic checking was conducted.

\section{i. $\quad$ Model Specification Test}

This study is based on the model proposed by different prior studies conducted in developed economies. There may be chance of specification error in the model due to addition and omission of some variables. Thus, a test is conducted to ensure the appropriate specification of the models. The given values of $\mathrm{F}$-statistics ( $\mathrm{F}=11.94$ and $\mathrm{p}$-value $0.0001<1 \%)$ in full model $\mathrm{V}$ of table 4 confirmed that the overall specification of the model is significant. The RESET test further confirmed that the fitted model is valid and there is no specification biased.

Ramsey's regression specification error test (RESET) Test:

H0: Model is properly specified

Test statistic: $\mathrm{F}=2.917$, with $\mathrm{p}$-value $=\mathrm{P}(\mathrm{F}(2,16)>2.917)=0.083$

Since, the F test is significant and p-value doesn't reject the null hypothesis at $5 \%$ level of significance, it could be claimed that model is not mis-specified.

\section{ii. Autocorrelation Test}

Breusch-Godfrey (LM) test for autocorrelation

H0: There is no serial autocorrelation

Test statistic: $\mathrm{LMF}=2.364553$, $\mathrm{p}$-value $=\mathrm{P}(\mathrm{F}(2,16)>2.36455)=0.126$

Since, $\mathrm{p}$ value of given statistics $(0.126)$ is greater than 0.05 , it couldn't 
reject the null hypothesis. Hence, the model is free from serial autocorrelation.

iii. $\quad$ Multicollinearity Test

The diagnostic check has been conducted using variance inflationary factor (VIF) of explanatory variables to detect the multicollinearity problem, if any. The values of VIF associated with several specifications of the model are reported in Appendix E. The result shows that VIF of explanatory variables across all the models are significantly lower than 10. Therefore, there is no evidence of Multicollinearity.

iv. Hetersokedasticity Test

White's test for heteroskedasticity

H0: Heteroscedasticity not present

Test statistic: $\mathrm{X}^{2}=16.342$, $\mathrm{p}$-value $=\mathrm{P}\left(\mathrm{X}^{2}(14)>16.341885\right)=0.292945$

Since $\mathrm{p}$-value $>0.05$, it could not reject the null hypothesis. That means there is no heteroscedasticy.

The summary of the results has been illustrated as below:

Table 8

Summary of Results

\begin{tabular}{|c|c|c|c|c|}
\hline Hypothesis & Independent variable & $\begin{array}{c}\text { Dependent } \\
\text { variable }\end{array}$ & $\begin{array}{l}\text { Hypothesized } \\
\text { relationship }\end{array}$ & Finding \\
\hline $\mathrm{H}_{1}$ & Real GDP & Market index & Positive & Supported \\
\hline $\mathrm{H}_{2}$ & Inflation & Market index & Positive & Supported \\
\hline $\mathrm{H}_{3}$ & Interest rate & Market index & Negative & Supported \\
\hline $\mathrm{H}_{4}$ & Broad money supply & Market index & Positive & Supported \\
\hline $\mathrm{H}_{5}$ & Macroeconomic variables & Market index & Long-run $\mathrm{Eq}^{\mathrm{m}}$ & Contradicted \\
\hline
\end{tabular}

\section{Conclusions}

The results documented in this study find the priori expected sign of relationship between stock prices and macroeconomic variables including real GDP, inflation, interest rate, and broad money supply. Their correlation coefficients as well as estimated regression coefficients are found statistically significant to predict stock prices. However, the study doesn't find long run- equilibrium relationship between macro-economy and stock prices and conclude that the macroeconomic variables could not explain the variation in stock prices in the long-run. This result contradicts the prior finding by Ibrahim and Aziz (2003), Bhattarai and Joshi (2009) and many others. However, this result is consistent with the findings by Pethe and Karnik (2000) and also supports the findings by Baskota (2007) in Nepalese context. Viewing from macroeconomic perspective, the results support the random walk hypothesis in Nepalese context.

\section{REFERENCES}

Abu-Libdeh, H. \& Harasheh, M. (2011). Testing for correlation and causality relationships between stock prices and macroeconomic variables: The case of Palestine Securities Exchange. 
International Review of Business Research Papers, 7(5), 141-154.

Adel, Al-S. (2004). The dynamic relationship between macroeconomic factors and the Jordanian stock market. International Journal of Applied Econometrics and Quantitative Studies, 1(1), 97-114.

Alagidede, P. \& Panagiotidis T. (2010). Can common stocks provide a hedge against inflation? Evidence from African countries. Review of Financial Economics, 19, 91-100.

Avadhani, V. A. (1996). Investment management. Bombay: Himalaya Publishing House.

Baskota, N.P. (2007). Stock price volatility in Nepal [Unpublished M. Phil. Thesis], FOM, Tribhuwan University.

Bernanke, B.S. (1983). Nonmonetary effects of the financial crises in the propagation of the great depression. American Economic Review, 73, 257-76.

Bhattarai, R.C. \& Joshi, N.K. (2009). Dynamic relationship among the stock market and macroeconomic factors: Evidence from Nepal. South Asia Economic Journal, 10(2), 451-469.

Chen, N., Roll, R. \& Ross, S.A. (1986). Economic forces and the stock market. Journal of Business, $56,383-403$.

Dickey, D. \& Fuller, W.A. (1981). Likelihood ration statistics for autoregressive time series with a unit root. Econometrica, 49, 1057-1072.

Engle, R. F. \& Granger, C.W.J. (1987). Cointegration and error correction: Representation, estimation and testing. Econometrica, 55, 251-276.

Fama, E.F. \& Schwert, G.W. (1977). Asset returns and inflation. Journal of Financial Economics, 5(2), 115-146.

Fama, E.F. (1970). Efficient capital markets: A review of theory and empirical work. The Journal of Finance, 25(2), 383-417

Fisher, I. (1930). The theory of interest. MacMillan: New York.

Flannery, M. J. \& Protopapadakis, A. A. (2002). Macroeconomic Factors do Influence Aggregate Stock Returns. Rev. Financial Stud., 15: 751-782.

Fung, H. G. \& Lie, C. J. (1990). Stock market and economic activities: A causal analysis. Pacific-Basin Capital Markets Research.

Gan, C., Lee, M., Yong, H. \& Jhang, J. (2006). Macroeconomic variables and stock market interactions: Newzealand evidence. Investment Management and Financial Innovations, 3, 89-101.

GC, S.B. \& Neupane, S. (2006). Stock market and economic development: A causality test. The Journal of Nepalese Business Studies, 3(1), 36-44.

Graham, B. (1973). The intelligent investor. Rev. Ed., Thomas Press India (2003).

Ibrahim, M.H. \& Aziz, H. (2003). Macroeconomic variables and the Malaysian equity market: A view through rolling subsamples. J. Econ. Stud., 30(1), 6-27.

Jennings, G. (2001). Tourism research. Queensland: John Wiley and Sons Ltd., Australia.

Kandir, S. (2008). Macroeconomic variables, firm characteristics and stock returns: Evidence from Turkey. International Research Journal of Finance and Economics, 16, 35-44.

KC, I. D. (2009). The cross section of stock market returns. Quantitative Analysis, 32, 463-489.

Maghayreh, A. (2003). Causal relations among stock prices and macroeconomic variables in the small, open economy of Jordan. Journal of King Abdul Aziz University, 17(2), 4-10.

Malkiel, B. G. (1989). Is the Stock Market Efficient? Science, 243, 1313-1318.

Markowitz, H. (1952). Portfolio selection. Journal of Finance, 7, 77-91.

Mukherjee, T. and A. Naka (1995). Dynamic Linkage Between Macroeconomic Variables and the Japanese Stock Market: An Application of a Vector Error Correction Model, Journal of Financial Research 18, 223-37. 


\section{Pravaha Journal-2018}

Osamwonyi, I.O. \& Osagie, E.I.E. (2012). The relationship between macroeconomic variables and stock market index in Nigeria. J Economics, 3(1), 55-63.

Pethe, A. \& Karnik, A. (2000). Do Indian stock market matters?: Stock market indices and macroeconomic variables. Economic and Political Weekly, 35(5), 349-356.

Pilinkus, D. (2009). Stock markets and macroeconomic variables: Evidences from Lithuania. Journal of Economics and Management. 14, 884-893.

Robert, R. (1932). The Dow Theory. Baron's: New York, NY.

Schwert, G. W. (1989). Why does stock market volatility change over time?. Journal of Finance, 44, 1115-1145.

Shrestha, P.K. \& Subedi, B.R. (2014). Determinants of stock market performance in Nepal. NRBEconomic Review, 26(2), 25-40. 